listing the child's interest in something that attracts him. The child's education should be attuned to his capability, and, while school discipline must be maintained, the more his teacher understands his disability and adopts an understanding and therapeutic rather than a punitive approach the better are the child's responses to his school environment likely to be. 6

Drugs, and paradoxically certain stimulant drugs in particular, have an important role in the treatment of the hyperkinetic child. 67 They may result in striking improvement, though their effect on the individual child is difficult to predict. Methylphenidate $(20-80 \mathrm{mg} /$ day) is the first choice. In many cases motor restlessness both at home and in school is reduced, to the relief of parents and teachers, and the child may perform better, with reduced clumsiness and improvement in fine movements-for instance, writing. Dexamphetamine (10-40 mg/day) has been found to be of almost equal value to methylphenidate. Diphenhydramine and chlorpromazine may be of some benefit, but phenobarbitone is contraindicated. Drug treatment is likely to be most successful in children with minimal cerebral dysfunction and some degree of intellectual impairment, least successful in children of normal intelligence whose behaviour is primarily psychogenic.

Treatment with stimulant drugs may have to be continued for months or even years and carries the risk of retardation of growth. ${ }^{8}$ Careful monitoring of height and weight during treatment is necessary. To reduce the liability to impairment of growth the treatment can be withdrawn during school holidays and weekends, when hyperkinetic behaviour may be more easily tolerated. Spontaneous diminution of hyperkinesia in later childhood is to be expected. Remission may begin by the age of 8-9 years. A combined programme of psychological guidance and drug therapy is said to be effective in about two-thirds of cases.

1 Werry, J. S., Learning Disorders, ed. J. Hellmuth, 3, 171. Seattle, Washington, Strauf and Hellmuth Special Child Publications, 1968.

2 Kenny, T. J., et al., fournal of Pediatrics, 1971, 79, 618.

3 Derby, B. M., New York State Fournal of Medicine, 1972, 72, 2061.

4 Coleman, M., fournal of Pediatrics, 1971, 78, 985.

5 Charlton, M. H., New York State Fournal of Medicine, 1972, 72, 2058.

- Eisenberg, L., Developmental Medicine and Child Neurology, 1966, 8, 593.

7 Eisenberg, L., New England fournal of Medicine, 1972, 287, 249.

8 Safer, D. Allen, R., and Barr, E., New England fournal of Medicine, $1972,287,217$.

\section{Treatment of Malignant Melanoma}

A notable feature of malignant melanoma is the unpredictability of its natural history. It is one of the few tumours in which spontaneous regression is well recognized, though rare.

The unpredictability of the disease has been highlighted in a report by F. G. Conrad. ${ }^{1}$ He describes five patients with advanced disease, including one with mediastinal involvement, who after either no treatment or local palliative excisions are alive and free from disease five to ten years later. Conrad also found that $17 \%$ of 170 patients with metastatic disease survived more than five years.

It is reports such as this, together with the great variation in reported results of treatment of melanoma, which make it so difficult to appraise the methods of treatment. For example, G. T. Pack and colleagues ${ }^{2}$ reviewed 1,000 cases and found only $21 \%$ free of disease after five years, and Sir Stanford Cade $^{3}$ reported $14 \%$ as surviving 10 years in his series. Yet the National Cancer Institute has shown that in stage I tumours (those without metastases in lymph nodes) the five-year survival rate was close to $80 \%$. There is no doubt that clinical involvement of the lymph nodes is a grave prognostic sign, and patients with it may have only a $5 \%$ chance of surviving five years. ${ }^{4}$ Two other characteristics of the disease influence treatment. One is the tendency to local recurrence, the other is the development of cutaneous and subcutaneous tumours between the primary site and the regional lymph nodes.

Controversy continues over the place of prophylactic block dissection of regional lymph nodes for stage I melanoma of the limbs. The argument in favour is based on the possibility that the clinically normal glands may yet contain malignant cells. G. $\mathrm{McNeer}^{5}$ found that $23 \%$ of 335 patients with clinically stage I disease had microscopic lesions in the regional nodes. Prophylactic block dissection has been advocated. ${ }^{6}$ Against that it is argued that the lymph nodes provide an important immunological defence mechanism. Block dissection has been shown to alter lymphatic dynamics, thus perhaps encouraging lymphatico-vascular communications as well as the direct spread of tumourbearing lymph to atypical areas of drainage, and it is reported to increase the incidence of multiple subcutaneous tumours. ${ }^{78}$ There is no statistical evidence that block dissection of regional nodes benefits patients with stage I melanoma, and until a controlled trial provides it one must be circumspect about performing an operation which is associated with a high morbidity. ${ }^{9}$

The position is different when the regional nodes contain metastases. Block dissection is then recommended. When the primary is near enough to the nodes, the dissection should be in continuity with excision of the primary tumour. ${ }^{10}$

In 1957 the late Oscar Creech introduced the technique of regional limb perfusion with cytotoxic drugs, and in 1966 W. T. Irvine and R. J. Luck ${ }^{11}$ reviewed their results of this treatment. It was shown that local disease could be destroyed by this method, but the prognosis was not obviously improved. A more recent unpublished study of their results in recurrent disease has shown no evidence that life is prolonged, though the local condition was often controlled. The average time of survival after perfusion for recurrent disease in a limb was 25 months. But now in a report of a much larger series E. T. Krementz and R. F. Ryan ${ }^{12}$ find that chemotherapy by regional perfusion adds $15 \%$ to the $5-$ year survival rate of stage I melanoma and doubles the survival rate in stage II cases. This was not a controlled trial, and the results are a general assessment by the authors. $\mathbf{A}$ prospective randomized study is necessary to determine the place of regional chemotherapy for this disease.

Endolymphatic infusion of radioisotope in combination with wide local excision of the primary tumour is another approach to the problem. The first isotope used was colloidal gold. ${ }^{13}$ Iodine- 131 and subsequently phosphorous-32 iodized o.1 superseded it. J. M. Edwards ${ }^{14}$ reported $82 \%$ 3- to 5-year survival rate in stage I disease, and the method is supported by I. M. Ariel and colleagues. ${ }^{15}$ The results are promising, the morbidity is low, but the conclusions of a Medical Research Council trial in progress must be awaited before its true benefits are known.

There is much to learn about this disease, but it is agreed 
that in the management of melanoma incisional biopsy must be avoided. The primary tumour must be excised with a very wide margin of skin at the earliest possible time and the defect covered with a skin graft. There seems to be very little place for major limb amputation. External radiotherapy produces a poor response in most cases.

1 Conrad, F. G., Gerber, D. M., and Scharnagel, I. M., Cancer, 1972, 30,

2 144. Pack, G. T., Annals of Surgery, 1952, 136, 905.

2 Pack, G. T., Annals of Surgery, 1952, 136, 905.
Cade, S., Annals of the Royal College of Surgeons of England; 1961, 28, 331.

4 Ackerman, L. V., and Del Regato, J. A., Cancer: Diagnosis, Treatment and Prognosis, 2nd edn., p. 195. St. Louis, Mosby, 1954.

${ }^{5}$ McNeer, G., Surgery, Gynecology and Obstetrics, 1965, 120, 343.

6 Southwick, H. W., et al., British fournal of Plastic Surgery, 1962, 15, 49.

Peterson, N. C., Bodenham, D. C., and Lloyd, O. C., British fournal of Plastic Surgery, 1962, 15, 49.

${ }^{8}$ Stehlin, J. S., Annals of the New York Academy of Sciences, 1963, 100, 128.

- Fortner, J. G., Booker, R. J., and Pack, G. T., Surgery, 1964, 55, 485.

10 Pack, G. T., Scharnagel, I., and Morfit, M., Surgery, 1945, 17, 849.

11 Irvine, W. T., and Luck, R. J., British Medical fournal, 1966, $1,770$.

12 Krementz, E. T., and Ryan, R. F., Annals of Surgery, 1972, 175, 900.

13 Jantet, G. H., British fournal of Radiology, 1962, 35, 692.

14 Edwards, j. M., Annals of the Royal College of Surgeons of England, 1969, 44, 237 .

15 Ariel, I. M., American fournal of Roentgenology and Radium Therapy, $1971,111,310$

\section{Particles in Veins}

The most dangerous particies that may contaminate intravenous fluid are live bacteria, ${ }^{1}$ and even dead organisms can cause serious pyrogenic reactions. The British Pharmacopoiea $^{2}$ therefore gives explicit instructions to ensure sterility and freedom from pyrogens, and these precautions have been strengthened by the Medicines Commission ${ }^{3}$ and Department of Health inspection since the Devonport disaster. Much briefer and less precise regulations govern the presence of larger particles. It is merely required that "solutions to be injected should not contain particles of foreign matter that can readily be observed on visual inspection."2 However, visual inspection does not detect particles below $50 \mu \mathrm{m}$ diameter, ${ }^{4}$ and attempts to standardize the test have been unsuccessful. 5 Sensitivity can be increased by the use of dark-ground illumination, 67 but the test remains subjective. The Coulter counter used in haematology has been adapted to this problem 48 and will probably be recommended in the next edition of the B.P., though some problems remain because of the heterogeneity of the particles encountered. 679 These include fragments of metal, glass, fibres, moulds, and even diatoms and insects. The most important source is disruption of rubber bungs when air trapped in their interstices expands during autoclaving, ${ }^{6}$ but inadequately washed bottles, membrane filters, air in the filling room, and the hair and gloves of factory workers have all been incriminated.

Now that a definable standard is emerging manufacturers will be stimulated to ensure minimum attainable contamination, since these particles, even if sterile, are not inert. They lodge in lung arterioles and capillaries, stimulating the growth of granulomata.7 1011 Cellulose fibres from jute, hemp, cotton, or paper are the most irritant ${ }^{7} 12$ and have been noted in the few lesions so far recognized in man. 81314 A few particles might pass through a patent foramen ovale or arteriovenous anastomoses in the lungs ${ }^{15}$ to reach the cerebral circulation, where they are equally irritant. ${ }^{7}$ The rubber bung, which is so important a source of particles, can be eliminated by the use of plastic bags. But plastics also pose problems. ${ }^{16}$ They contain additives almost as numerous as the diverse materials that make up "medical grade rubber," and the leaching out of one such chemical was probably responsible for a recent outbreak of jaundice. ${ }^{17}$ It is therefore 'unlikely that glass bottles will disappear from the pharmacy in the near future. Their problems do not end when they leave the factory particles: are shed during storage, ${ }^{78}$ and it is difficult to ensure rapid rotation of stock with a short shelf life in a large hospital using many different intravenous solutions. ${ }^{9}$ Moreover, new particles may be added along with drugs and other additives. A myriad of glass particles was identified in an infusion of frusemide prepared by opening 160 ampoules. 19

The incorporation of a terminal filter in drip sets is therefore an attractive proposition and one which has been shown to reduce particulate contamination even though the filter itself sheds some fibres. ${ }^{818}$ The routine use of such filters would add considerably to the cost of intravenous therapy, which is already rising geometrically. It would increase the cost of the drip set and the number used, since a non-filter set would have to be substituted whenever blood or fat emulsions were given. Is the danger from particles sufficient to justify this substantial increase in cost? Perhaps not, on present evidence. However, there is another argument for incorporating a fine filter in drip sets. J. A. Myers ${ }^{18}$ grew bacteria from 6 of 25 such filters during short-term infusions. Bacterial contamination of indwelling cannulae and septicaemia are the major hazards of prolonged intravenous therapy, ${ }^{19-21}$ and the beneficial effects of careful asepsis ${ }^{22-24}$ suggest that bacteria are usually introduced down the drip set. A bacterial filter will probably justify its cost on this ground alone, and the elimination of scrap metal, bits of reclaimed motor tires, ${ }^{7}$ ants, ${ }^{25}$ and all the other flotsam and jetsam that somehow finds its way into intravenous fluid will be a. welcome consequence.

1 British Medical fournal, 1972, 3, 190.

2 British Pharmacopoiea. London, Pharmaceutical Press, 1968.

Department of Health and Social Security, Interim Report on Heat Sterilised Fluids for Parenteral Administration. London, H.M.S.O., 1972. Sterilised Fluids for Parenteral Administ
Groves, M. J., Analyst, 1969, 94, 992.

Groves, M. J., Analyst, 1969, 94, 992. Symposium Proceedings, p. 6. Washington, U.S. Food and Drug Administration, 1966.

- Garvan, J. M., and Gunner, B. W., Medical fournal of Australia, 1963,

7 Garvan, J. M., and Gunner, B. W., Medical fournal of Australia, 1964, 2,1 .

8 Groves, M. J., Pharmaceutical fournal, 1972, 208, 550

Yakowitz, M. L., in Safety of Large Volume Parenteral Solutions, National Symposium Proceedings, p. 3. Washington, U.S. Food and Drug Administration, 1966.

10 Jonas, A. M., in Safety of Large Volume Parenteral Solutions, National Symposium Proceedings, p. 23. Washington, U.S. Food and Drug Administration, 1966.

11 Gross, M. A., and Carter, C. J., in Safety of Large Volume Parenteral Solutions, National Symposium Proceedings, p. 31 . Washington, U.S. Folutions, National Symposium Proceedis

12 Wartman, W. B., Hudson, B., and Jennings, R. B., Circulation, 1951, 4, 756.

13 Brüning, E. J., Virchows Archiv, 1955, 327, 460.

14 Sarrut, S., and Nezelof, C., La Presse Medicale, 1960, 68, 375.

15 Hales, M. R., American fournal of Pathology, 1956, 32, 927.

16 Autian, J., in Safety of Large Volume Parenteral Solutions, National Symposium Proceedings, p. 38. Washington, U.S. Food and Drug Administration, 1966.

17 Neergaard, J., Nielsen, B., Faurby, V., Christensen, D. H., and Nielsen O. F., Scandinavian fournal of Urology and Nephrology, 1971, 5, 141 18 Myers, J. A., Pharmaceutical fournal, 1972, 208, 547.

19 Turco, S., and Davis, N. M., New England fournal of Medicine, 1972, 287,

20 Banks, D. C., Yates, D. B., Cawdrey, H. M., Harries, M. G., and Kidner, P. H., Lancet, 1970, 1, 443.

21 Curry, C. R., and Quie, P. G., New England Fournai of Medicine, 1971, $285,1221$.

${ }_{22}^{22}$ Freeman, R., and King, B., Lancet, 1972, 1, 992.

23 Colvin, M. P., Blogg, C. E., Savege, T. M., Jarvis, J. D., and Strunin, L., Lancet, 1972, 2, 317 .

24 Winters, R. W., Santulli, T. V., Heird, W. C., Schullinger, J. N., and Driscoll, J. M., New England fournal of Medicine, 1972, 286, 321 .

${ }^{25}$ Rupp, C. A., and Forni, P., New England fournal of Medicine, 1972, 286, 